\title{
The Impact of Livestock Extension on the Livelihood of Mbororo Fulani Women in the North West Region of Cameroon
}

\author{
Loveline Enjoh Forbang (Corresponding Author), Tohnian Nobert Lengha \\ Department of Integrated Rural Development and Agricultural Extension, University of \\ Dschang, Cameroon. E-mail: lovelineenjoh@yahoo.com
}

Fonteh Athanasius Amungwa

Department of Sociology and Anthropology, University of Buea, Republic of Cameroon

$\begin{array}{lrr}\text { Received: May 20, } 2019 & \text { Accepted: May 15, } 2020 \quad \text { Published: May 22, } 2020 \\ \text { doi:10.5296/jas.v8i2.17076 } & \text { URL: https://doi.org/10.5296/jas.v8i2.17076 }\end{array}$

\begin{abstract}
Mbororo Fulani women are experiencing transformation in their livelihood through livestock farming. This paper investigates the contributions of livestock farming to the wellbeing of the Mbororo Fulani women of the North West region of Cameroon. Mbororo women in the North West region play different roles to contribute to the growth of the livestock sector in Cameroon but lack technological knowledge and extension services to improve on their livestock activities. The study used primary data gotten through structured questionnaires and secondary data from journals, books and work from other researchers. The simple random sampling was used to select 400 Mbororo women for the study and SPSS was used for data analysis. The study reveals that $61 \%$ of Mbororo women are engage in livestock farming. $20.4 \%$ of the women keep different categories of livestock extension (sheep, goat, poultry etc). $89 \%$ of the women do livestock farming for income generation and as a means to increase proteins needs for their families. Therefore, livestock is an important source of revenue to Mbororo Fulani women in the North West region of Cameroon thus Cameroon government should put more efforts to assist these Mbororo women in livestock farming by providing them with modern innovations through extension services and resources needed to expand on livestock farming.
\end{abstract}

Keywords: Agriculture, Empowering, Economic, Transformation, Technologies, Region 


\section{Introduction}

The focus of this study is to show the impact of livestock farming on the livelihood of Mbororo Fulani women in the North West Region of Cameroon. Studies have shown that proper livestock farming can only be achieved through the provision of suitable innovations and technologies (Ugwoke, 2016). Extension services play an important role in empowering farmers with suitable technological knowledge and skills through various education and training programs (Ibrahim,2015). The concept of livestock extension with a focus on women seeks to provide a holistic understanding of the technologies needed to increase livestock production among Mbororo women in the North West region. Agricultural extension services and livestock ministries have the obligation to improve these services to the farmers if they have to meet the needs to assist women ameliorate their living condition. To achieve this, one of the solutions lies in decentralization of all extension services and livestock information delivery under local structures in response to local needs and conditions. When we think of ways to increase women's participation in livestock markets, we should think of increasing their ability to sell animals or animal products (World Bank 2012). This can be an important way to improve the welfare of women and their families. But if women are unable to make decisions about which products and animals are sold and what is done with the incomes of the sale, the activity may not benefit women (Ayoade,2015). Helping women gain access to labour, product and service markets and improving their living conditions are ways in which women can benefit from participation in livestock production and markets. In Nigeria for instance, although are highly involved in the management of animal by providing them with feed, they only feed their families from the processing and sales of butter and cheese. They are not involved in livestock marketing or managing livestock diseases. Men on the other hand, take the animals for veterinary treatment when the need arises (Barbercheck,2014). The case of Cameroon is not different where women are given less valued aspects of livestock to manage and the men occupy the most valued part of livestock. While women play many of these roles along the value chain, most literature mainly cites their roles as suppliers of livestock products, particularly milk products, and other processed of animal foods with no focus on the amelioration of their living condition especially of the minority Mbororo women.

According to the livestock development project in Cameroon (LDPC2016), the livestock sector has a strong bearing on poverty-troubled societies, either directly through the provision of food products and services such as animal draught power and transport or indirectly through the provision of employment and wealth creation. The purpose of this study is to show the effect of livestock farming on the livelihood of Mbororo Fulani women of North West region of Cameroon.

\section{Material and Methods}

Population Size

The North West region has a total population of about 1,728,953inhabitants Cameroon 2005 population and Housing Census (CPHC, 2005). With about 3466 registered Fulani herder's households (Ministry of Livestock, Fisheries and Animal Industries (MINEPIA 2015; Manu 
et al. 2014). The population of the study is selected from four divisions within the North West namely; Mezam, Boyo and Momo and Donga-Matung divisions. The population were drown from the following villages; Acha-Tugi, Ntabang and Fundong, Sabga and Nkambe. These areas were selected for the study because they are highly populated with Mbororos and livestock farming are higher. The focus of the work is on Mbororos female farmer's age 21-60 years.

\section{Sampling Techniques}

Simple random sampling was used for the study. The random sampling method gave us the possibility to randomly select female respondents for the study making sure that everyone Mbororo woman was considered with no biased in the study and to ensure accuracy. The random sampling method is a process that builds an inherent "fairness" into the research being conducted because no previous information about the women involved in the study are included in the data collection process. Mbororo people are distributed all the seven divisions in North West region but this study is conducted in four of the seven division.

Procedures for Sampling Size

The population from which the sample was drown was Mbororo female farmers in four of the seven divisions of Northwest region. To select our sample size we used the Yamane (1967) Formula for Calculating a Sample size to ensure maximum variability in the study. The formula is assume to be $\mathrm{p}=.5$ which is maximum variability. The formula state that if a population is greater than one hundred thousand $(>100,000)$ the sample size is taken at four hundred (400) which will give a degree of confidence level which could be $\pm 5 \%$ precision. In this case the formula is;

$$
\mathrm{n}=\frac{N}{1+\mathrm{N}(\mathrm{e}) 2}
$$

$\mathrm{n}=$ the sample size

$\mathrm{N}=$ the size of population and

$\mathrm{e}=$ the margin of error $(0.05)$ when the confidence level is $95 \%$

Thus the sample size for the study was 400 hundred (Table 1) assuming that female Mbororo women in North West region are more than 100,000 distributed within seven divisions.

Table 1. Spatial distribution of sampling by divisions

\begin{tabular}{llllll}
\hline Divisions & Mezam & Momo & Boyo & Donga-Mantung & Total \\
\cline { 2 - 6 } & 125 & 75 & 100 & 100 & 400 \\
\hline
\end{tabular}

Source: Field survey 2018

This spatial distribution was based on the observation that although Mbororo people are present in all divisions of North West Region, some divisions are highly populated with Mbororo than the others and this is due to the availability of grazer land and settlement space. 
Data Collection and Methods

Data for this study was collected between March 2017 and April 2018. The data for this work was obtained from both primary and secondary sources. That is, primary data was collected through structured questionnaires, interviews guides, observations guides, while secondary data was collected through books, articles and journals. The questionnaires were made of close-ended question to ease the respondent considering the fact that the women are not very educated.

Interview

Semi structured interview were used in the collection of qualitative data. Resource persons interviewed for the study were the sub-divisional delegates of livestock in the study area (Tubah, Bafut, Mbengwi and Nkambe). Questions asked were selected from the questionnaire and answers were done through discussions. The researcher paid attention whenever the interviewee was responding to a question to avoid repeating a question whose response had already been provided by the interviewee while responding to another question. This was necessary to save time and to prevent the interview from becoming boring. All the answers that were given by the interviewee were written down for further analysis. This gave the research solid information about the situation of the Mbororo women in livestock production in the North West.

Observations

Observation method of data collection was also used in collecting primary data for the study. The researcher made observations guides by providing some modalities through answer could be gotten from questionnaires. For example stating the different age range (21-30) or stating the educational level of the respondents. This permits us to evaluate better farmer's perception on extension delivery approaches used by extension workers as seen. Considering the fact that most of the Mbororo women are not very educated, questionnaires were read out to them and explanation done while taking down their responses. Also, the fact that the Mbororo women use in the study are not very educated, most of the work was done using Pidgin English, a "lingual Franca" language commonly spoken in the North West Region. In some cases translation was done from English to "fulfude" to those who could not be able to understand the English language well. The questionnaires were eventually filled by the researcher for efficiency reason.

\section{Results and Discussion}

Demographic Information

Age is an important demographic variable and a primary basis of demography in vital statistics, census, and surveys (Eicher,2016). It gives pictures of a household's labor and income. The women were of different age groups. The lowest groups of respondents for the study were women from 60 and above with $3 \%$ (Fig. 1). 38\% of the women interviewed for the study were women between 41-50years followed by 31-40 (34\%) Few of the women also fell between 21-30 giving (9\%). From these results we can see that the age group that is greatly involved in livestock farming are women of age 31-50. The results are significant to the study 
because in any growing population this age group 31-50 is the most active. This indicates that most women at the middle age are more productive than at old age and lowest age therefore there is a need to empower them in their opportunities for income generating activities through livestock faming. Composition of household members in terms of their age distribution has implications on the household ability to meet its food requirements (Enujeke, 2015). According to Tarla (2016), the age range of 21-50 is an active age for farming and farmers of this age are usually willing to adopt measures or technologies. Statistics from a South Africa Community Survey 2016 on female livestock farming revealed that $21,5 \%$ of women in livestock farming are between the ages of 45-54 and the women are mostly engaged in 'poultry farming only. This is almost the same case in Cameroon where poultry is said to be the most suitable livestock for women.

Education is valued as a means of liberation from ignorance which enables one to perform effectively in economic activities. On the level of education on Table 2, illiteracy level of respondents is still very high. $38.9 \%$ of women have not gone to school at all, $27.1 \%$ of them did not complete primary school. Only $21.3 \%$ of the respondents completed primary school. $12.7 \%$ of the respondent went to secondary school and only $5.7 \%$. In addition, the traditions and customs of the Mbororo forced girls in to early marriages which hinder them of their right to education. The high illiteracy level makes it difficult for the women to actively take part in seeking information regarding income generating activities and have limited access to extension services. (Fransman, 2014) explained that education plays an important role in adopting a new system of farming. As farmers acquire more education, their ability to obtain and use information increases and also enhances farmers' ability to obtain, analyze and interpret information. Baruwa, et al. (2015) added that education is expected to influence the perception of farmers and enhance adaptation of innovation among farmers. The story today has change as we can find more Mbororo girls in schools and even higher education influenced by their parents. Therefore the more women are educated, the more they can expand their scope of production through the adoption and application of new technologies.

Table 2. The level of education of the women was as follows

\begin{tabular}{l|l|l}
\hline Level & Number of women & $\%$ \\
\hline No school & 95 & 38.9 \\
\hline Did not complete primary school & 66 & 27.1 \\
\hline Completed primary school & 52 & 21.3 \\
\hline Did not complete secondary school & 17 & 7 \\
\hline Completed secondary school & 14 & 5.7 \\
\hline Higher education & 0 & 0 \\
\hline Total & 244 & 100 \\
\hline
\end{tabular}

Source: Field survey 2018 


\section{Macrothink}

Women participation in livestock farming

Mbororo women are becoming active participant in livestock production through support provided by various state agents. Out of the 400 respondent that were sample for the study, 244 women were involved in livestock farming. Statistics from (table 3) revealed that $61 \%$ of the women keep livestock and only $39 \%$ are not involved in livestock farming. The awareness on the importance of livestock as an economic activity is recognized by most of the Mbororo women. This result comes to wipe out the notion that, Mbororo women are not involved in livestock farming. They are involved in a variety of livestock related activity and only within their respective communities. According to IFAD (2016), "where poverty is rampant, livestock represent an important asset for local, cultural and socio-economic growth". Women are considered to be greatly affected by poverty thus their engagements in livestock can go a long way to improve on their income generating activities and improved on their livelihood.

Table 3. Involvement in livestock farming

\begin{tabular}{clcc}
\hline & & Frequency & Valid Percent \\
\hline & yes & 244 & 61.0 \\
& no & 156 & 39.0 \\
& Total & 400 & 100.0 \\
Total & & & \\
\hline
\end{tabular}

Source: Field survey 2018

The women are involved in various categories of livestock as shown on the (table 4). In Yemen for example, women have greater involvement in activities related to agriculture and livestock, including goats, camels, and cows. Rural women in Yemen spend more than five hours in the management and controlling of sheep (Ugwoke, 2015) thus if these women who are into livestock can put in much efforts it will yield them high income.

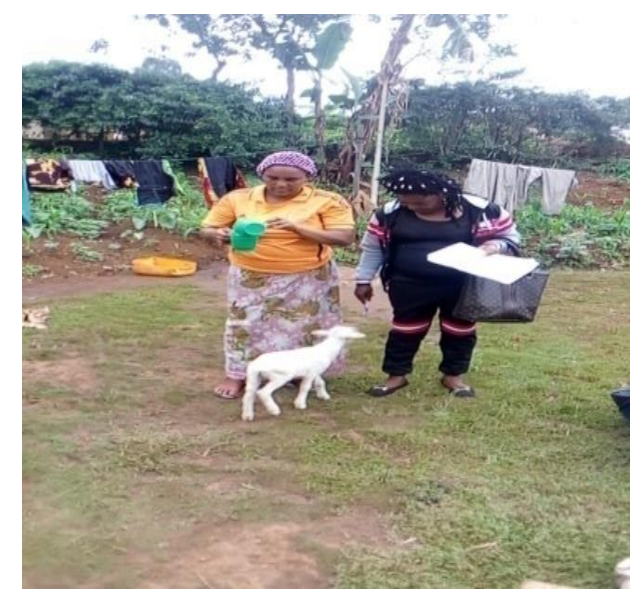

Source: Field work 2018 
Table 4. Reasons for involvement in livestock farming

\begin{tabular}{ccc}
\hline $\begin{array}{l}\text { Reasons for involvement } \\
\text { livestock farming }\end{array}$ & Frequency & Cumulative Percent \\
food & 35 & 14.3 \\
for income & 27 & 25.4 \\
both & 182 & 100.0 \\
Total & 244 & \\
\hline
\end{tabular}

Source: Field survey 2018

The picture of the researcher while in the field folowing up the activities of a Mbororo woman in the Sabga community taking care of her livestock at home. The woman is actually nurishing the sheep using milk at home and this mbororo lady has taken livestock as her main economic activity and she goes round buys the livestocks and takes them to the market for sales weekly.

Reasons for involvement into livestock farming

From the (table 5), Mbororo women in livestock farming do it for various reasons. Statistics from above show that a majority of the women (89\%) do livestock farming as income generating activity and as a means to increase nutritional (proteins) for their families. Only few of the women (11\%) see and use livestock farming as an income generating activity only. These results are evident to the fact that livestock farming is an important income generating activity for most of the women and can improve on the wellbeing of the women. About half of them depend directly or indirectly on livestock for their livelihoods. Livestock can be sold in times of crisis thus act as household insurance (World Bank 2016). In an interview with Mama Bouba Hajah in one of the research community in Sabga, when ask the "question of why she is involved in livestock farming", she said all her children's education and health depends on livestock. She sell both the animals and byproducts (milk, butter) to care for her family when need arise. Therefore as the population continues to increase, more effort and innovation and techniques are needed in order to sustain and increase agricultural production (livestock). This will ensure that those who are suffering from malnutrition have access to nutritious food. World leaders at the 2012 Conference on Sustainable Development (Rio+20) reaffirmed the right of everyone to have access to safe nutritious food. Empowering women through livestock faming is therefore fundamental to reduce hunger and improve food security. The World Bank's World Development Report 2012 adds that gender involvement in economics has high economic costs thus need to be address timely. In Afghan society for example, the National Risks and Vulnerability Assessment (NRVA) of 2011-2012) acknowledges livestock farming as the economic backbone. The government of Cameroon has the responsibility to support the women through sustainable agriculture by empowering women in livestock farming and promoting gender equality of rural women to ensure healthy lifestyles and improve nutrition through livestock. This cannot be accomplished without educating the women on the use of extension services. 


\section{Macrothink}

Table 5. Type of livestock practice by the women

\begin{tabular}{lcc}
\hline Types of livestock's & Frequency & Percent \\
\hline poultry & 15 & 6.1 \\
goat & 13 & 11.5 \\
cattle & 36 & 26.2 \\
sheep & 15 & 32.4 \\
Goat \& sheep & 2 & 33.2 \\
goat, sheep \& poultry & 12 & 38.1 \\
pigs & 44 & 56.1 \\
goat, sheep, cattle's, \& poultry & 50 & 76.6 \\
Cattle \& sheep & 22 & 85.7 \\
Sheep \& poultry & 35 & 100.0 \\
\multicolumn{2}{c}{ Total } & 244 \\
\hline
\end{tabular}

Source: Field survey 2018

\section{Income level of farmers from livestock activities}

Most of the women 45.5\% make just a minimum income ranging between 20,000-50,000 and $29.5 \%$ are able to make between $100000-500000$ thousand while only $2.9 \%$ of the farmers are able to make above 1000000 million from their livestock activities (Table 6). This show that the activity is still slow among the women and the income they make from livestock is not sustainable. Therefore the women need to be encouraged to take livestock as an income generating activity and invest lots of interest for it. This goes to confirm with the results on where the women have only receives little assistance to promote their livestock farming and that shows that that little has been done in increasing the scope of technological assistance to the women. Therefore if these women are provided with much of technology and material assistance it will have a positive impact on the income level of the women to improve on their livelihood.

Table 6. Income level of farmers from livestock activities

\begin{tabular}{lll}
\hline Amount in CFA & Respondents & $\%$ \\
\hline $20,000-50,000$ & 111 & 45.5 \\
$51,000-100,000$ & 31 & 12.7 \\
$101,000-500,000$ & 72 & 29.5 \\
$501,000-1,000,000$ & 14 & 5.7 \\
Above $1,000,000$ & 7 & 2.9 \\
None of the above & 9 & 3.7 \\
Total & 244 & 100 \\
\hline
\end{tabular}

Source: Field survey 2018 
Table 7. Level of improvement of living condition through livestock

\begin{tabular}{ccc}
\hline farming & & \\
Levels of improvement & Frequency & Percent \\
low & 55 & 22.5 \\
very low & 27 & 11.1 \\
high & 112 & 45.9 \\
very high & 49 & 20.1 \\
& & $\cdot$ \\
Total & 244 & 100.0 \\
\hline
\end{tabular}

Source: Field survey 2018

Contribution of livestock extension on the livelihood of Mbororo women

Over $78 \%$ of Mbororo Fulani livestock farmers agree that livestock farming has greatly improve on their living conditions. When asked the level at which livestock has improve their live most of them(78.6\%) say that livestock activity has highly improved their living conditions while (21.7\%) say that the level of improvement is still low. Based on the results on (table 8), we can conclude that the Mbororo women actually acknowledged that livestock can change their living condition if they continue with the activity and if they are provided with greater assistance.

Table 8. Livestock as a good source of revenue for Mbororo women

\begin{tabular}{lrr}
\hline Modalities & Frequency & Percent \\
\hline strongly agree & 7 & 2.9 \\
disagree & 17 & 7.0 \\
strongly agree & 98 & 40.2 \\
agree & 122 & 50.0 \\
Total & 244 & 100.0 \\
& 163 & \\
\hline
\end{tabular}

Source: Field survey 2018

Livestock as a good source of income to the Mbororo women

From (table 9) we can see that while $50.4 \%$ of the women agree that livestock is an important source of revenue to them $39.3 \%$ of the women also strongly agree to the fact that live stock is a good source of income generating activities to them. Never the less some of the women still do not recognized the important of livestock to their livelihood as some $(10.1 \%)$ of the women either disagree or strongly disagree that livestock farming does not improve on their living condition.

\section{Discussion}

It is evident from the study that female livestock farming can be an effective way to ameliorate the living condition of female household. But this cannot be achieved if proper extension services are not rendered to these women. Involving women in livestock through 
education and training is of great importance. Training helps to achieve a better understanding on how to improve on livestock farming. Through training women can be able to improve quality of their livestock, improve production techniques, and take appropriate care of the animal in order to prevent losses. Education of women provides them with access to appropriate technology and increase food production and as a result, will improve household's standard of living. Extension services contribute to agricultural sustainability, livelihood improvement and well-being of populations in rural areas (GFRAS 2010; Meinzen-Dick et al. 2012). The stakeholders responsible for the provision of these services are the government, NGO and private individuals or volunteers. Given women's traditional responsibility for household food security, their level of control over decisions about whether to sell or consume the family's animal products, as well as over how to use any income obtained from the sale of animal foods, could greatly determine the nutritional wellbeing of household members (P Kristjanson, A Waters-Bayer, 2014). Thus the study on the impact of livestock extension with a case study on Mbororo Fulani women of the North West Region of Cameroon is intended to show how important livestock farming can help women improve on their wellbeing.

\section{Conclusion}

The purpose of this study was to show the impact of livestock farming on the livelihood of the Mbororo Fulani women of North West Region of Cameroon. From the results, there is sufficient evidence that livestock is a good source of income to the Mbororo women of North West region of Cameroon as $61 \%$ of the Mbororo women are into livestock farming. Livestock contribute to household livelihoods by providing income and a source of protein to the household. The women are involved in different categories of livestock farming such as sheep, goat, cattle's and poultry. Income generated from livestock farming is low as $45.5 \%$ of the respondents can make just a monthly income of about 20000-50000 francs. Failure of effective extension services to the women in livestock farming is caused by several factors associated to their lifestyle and geographic factors. For example, the geographical location of the Mbororo communities makes it difficult for extension agents to reach them on regular basis since they live on hill top with no good roads leading to their communities. The poor income is influence by low technology and lack of knowledge needed to improve on the quality of livestock by the women.

\section{Recommendations}

Farmers need inputs to increase production, but access to these inputs is often poor for efficiency in extension services. Government should provide favorable bank policies to women that facilitate access to credit to the farmers and improve on material inputs to facilitate the livestock farming. This can be achieved by providing women with bank policies that are void of collaterals as precondition to obtain credit, providing the female livestock farmers with improve animal breed and technology to manage them.

Mbororo women should be encouraged to take livestock seriously as it can go a long way to improve on their living conditions. The government of Cameroon should also provide these women with innovations and technologies needed for quality livestock farming. Extension 
agents have the responsibility to assist these female livestock farmers with technologies to improve in both quantity and quality for greater achievement in the quality of livelihood.

\section{Acknowledgements}

I acknowledge the contributions of scholars like Prof. Ajaga Nji, Prof. Manu, Prof. Bup Divine who took time out of their schedule to follow me throughout the writing of this work. Profound thanks to my parents Mr./Mrs Nkwain for their countless efforts through financial, moral, and material support toward the accomplishment of this work.Greater thanks goes to some adorable class mates like madam patience, Mr. Fru Kenneth, Fri Achu, Mr. Ngalla Djibrila, whom we spent sleepless nights to discuss on issues relating to the completion of this work.

\section{References}

Ayoade, J. A., Ibrahim, H. I., \& Ibrahim, H. Y. (2015). Analysis of women involvement in livestock production in Lafia area of Nasarawa State, Nigeria. Livestock Research for Rural Development, 21, 220. (Available from http://www.lrrd.org//rrd21/12/ayoa21220.htm) (Accessed on 14 January 2017).

Barbercheck et al., (2014). Taylor, \& Fransman (2014). Meeting the Extension Needs of Women Farmers: A Perspective from Pennsylvania.

Eicher, C. K. (20016). Africa's Unfinished Business: Building Sustainable Agricultural Research Systems. Staff paper 20001-10, Department of Agricultural Economics, Michigan State University. East Lansing, Michigan.

Enujeke, E. C., \& Ofuoku, A. U. (2015). Determinants of adaptation to climate change among arable crop farmers in Edo state, Nigeria and its implications for extension service. International Journal of Advance Biological Research, 2, 220-227.

IFAD/FAO Engagement in Pastoral Development (2016). Joint Evaluation Synthesis

Manu, I., Andu, W., Tarla, N., \& Agharih, W. (2016). Causes of cattle theft in the Northwest region of Cameroon. Scholarly Journal of Agricultural Science, 4(4), 181-187.

MINEPIA (Ministry of Livestock, Fisheries and Animal Husbandry). (2015). Northwest Regional Delegation annual report. Bamenda-Cameroon.

Norusis, M. J. (1990). SPSS Introductory Statistics Guide. Chicago: SPSS, Inc.

Taylor, P., \& Fransman, J. (2014). Learning and teaching participation: exploring the role of higher learning institutions as agents of development and social change. Brighton, England: Institute of Development Studies Working Paper 219.

Ugwoke, F. O., Anaeto, F. C., Asiabaka, C. C., Nnadi,F.N., Ajaero, J. O., Aja, O. O., ... Onweagba, A. E. (2016). The role of extension officers and extension services in the development of agriculture in Nigeria. J. Agric. Res., 1(6),180-185. 


\section{Macrothink}

Journal of Agricultural Studies

ISSN 2166-0379 2020, Vol. 8, No. 2

Ugwoke, F. O., Adesope, O. M., \& Ibe, F. C. (2015). Youths' participation in farming activities in rural areas of Imo State, Nigeria: Implications for extension. Journal of Agricultural Extension, 8, 136-141.

World Bank (2016). Intensification of Livestock Production Systems in the North West Region of Cameroon: A South-to-South Collaboration for Technology Transfer - The Tugi Silvopastoral Report Number: 66794-CM. The World Bank, 1818 H Street NW, Washington, DC 20433, USA

Yamane, T. (1967). Statistics: An Introductory Analysis, 2nd Edition, New York: Harper and Row

\section{Copyright Disclaimer}

Copyright for this article is retained by the author(s), with first publication rights granted to the journal.

This is an open-access article distributed under the terms and conditions of the Creative Commons Attribution license (http://creativecommons.org/licenses/by/4.0/). 